\title{
Four Miao Ballads from Hainan
}

\section{Citation}

Idema, Wilt L. 2010. “Four Miao Ballads from Hainan.” CHINOPERL 29 (1) (June): 143-182.

doi:10.1179/chi.2010.29.1.143.

\section{Published Version}

doi:10.1179/chi.2010.29.1.143

\section{Permanent link}

http://nrs.harvard.edu/urn-3:HUL.InstRepos:34737826

\section{Terms of Use}

This article was downloaded from Harvard University's DASH repository, and is made available under the terms and conditions applicable to Open Access Policy Articles, as set forth at http:// nrs.harvard.edu/urn-3:HUL.InstRepos:dash.current.terms-of-use\#OAP

\section{Share Your Story}

The Harvard community has made this article openly available.

Please share how this access benefits you. Submit a story.

Accessibility 
There is a query attached to note 6

\section{Four Miao Ballads from Hainan}

Very little Chinese popular narrative verse is available in English. For a long time such a situation could perhaps be excused because many of the materials were not easily available. This situation has changed with the ongoing compilation and publication of the Compendium of Chinese Folksong (Zhongguo geyao jicheng 中 國歌謠集成) and the local collections on which each of the provincial volumes in that series were based. While the overwhelming majority of the materials in these collections consist of short lyrical songs, each volume also contains a section of narrative songs, which make many otherwise previously unavailable materials easily accessible, and greatly facilitates our work of studying and introducing popular narrative verse from all over China in all its diversity in terms of topic and form. At this stage each selection of materials for translation has to be arbitrary to a large extent. I came across the four texts translated here more or less by accident when I was leafing through the various volumes of the Compendium of Chinese Folksong looking for versions of the "Four Great Folktales." I was struck by the subject-matter and style of these four ballads, and believe they well merited translation, not only as representative examples of one highly specific local tradition, but also as literary works of considerable power. 
While the Miao are often listed as one of Hainan's major ethnic groups alongside the Han and the Li, they are actually very small in number, making up less than one percent of the total population. The majority of the Miao live in small dispersed settlements in the interior of the island. The first ethnographic description of the Hainan Miao was provided by the German ethnographer H. Stübel in his Die Li-Stämme der Insel Hainan: Ein Beitrag zur Volkskunde Südchinas (The Li Tribes of Hainan: A Contribution to the Ethnology of Southern China) of $1937 .{ }^{1}$ In the Appendix devoted to the Miao, Stübel notes that only a few Miao knew Chinese characters. "The only exception was the old village headman of Nam-pu, who in his youth had traveled throughout Hainan ....With great care he had compiled a Miao song book, from which he sang something for us, and from which we were allowed after long negotiations to copy a poem about the activities during the twelve months of the year that must have been of Chinese origin" (p. 239). Stübel notes that the text contained many faulty characters and proceeds to provide a translation. The poem consists of twelve four-line stanzas, each devoted to one month of the year (pp. 239-41).

More intensive ethnographic research was conducted on Hainan in the 1950's by the staff of the South-Central Institute for Minorities (Zhongnan minzu xueyuan 中南民族學院), but the resulting material on $22 \mathrm{Li}$ villages and two Miao villages was only made available in internal publications. The material on the $\mathrm{Li}$ villages was revised by the Institute and published for wider circulation in two

\footnotetext{
${ }^{1}$ Berlin: Klinkhardt und Biermann, 1937. The descriptions were based on trips made in 1931 and 1932.
} 
volumes in 1992 as A Social Survey of the Li Minority on Hainan Island (Hainandao Lizu shehui diaocha 海南島黎族社會調查). ${ }^{4}$ The material on the two Miao villages was revised by the same institution (which had become a university in 2002) and published more recently as A Social Survey of the Miao Minority on Hainan Island (Hainandao Miaozu shehui diaocha 海南島苗族社會 調查). ${ }^{5}$ One of these villages had been missionized and lost much of its traditional culture, but the village of Yananbiao 牙南表 in Honggou 紅溝 township of Baoting 保亭 district had in the early fifties a vibrant culture of songs and ballads, from which the researchers often quote throughout their description of village life and village beliefs. The researchers provide the following general description of the song culture in Yananbiao:

Among the Miao men and women, old and young all love to sing. Especially young men and women are expert singers. As they practice free love, they use the singing of songs as their matchmaker. But middle-aged and older people will likewise at wedding banquets and other festive occasions open their throat and sing loudly, and there is no end to their joy. From this we can see that the singing of songs is an important cultural activity and social skill among the Miao.

\footnotetext{
${ }^{4}$ Nanning: Guangxi minzu, 1992.

${ }^{5}$ Beijing: Minzu chuban she, 2010.
} 
苗族無論男女老幼, 都喜歡唱歌, 青年男女更是唱歌的能手.他們

自由戀愛,便借唱歌做媒介.中年或老年人在婚宴盛會上,也一樣

引吭高歌,樂而不綴.由此可見,唱歌已成為,苗族社會主要的文娛

活動與社交技能了.

The book identifies main three occasions on which the Miao sing and says the following about them:

1. Weddings and other festive gatherings 婚宴或其他盛會.

It is on these occasions that the opportunities for singing songs were most numerous. When singing in alternation there is no restriction on gender or age (at wedding parties the bride and groom do not sing). The words of the songs are all fixed. There are manuscript songbooks, and their contents mostly concern historical stories, such as The Song of King Pan). ${ }^{6}$ 以這種場合唱歌的機會最多, 對唱是不限男女, 也不論年幼(婚宴上新郎 新娘不唱),歌詞都是固定的,有手抄的歌本,內容多是歷史故事之類,如 盤王歌.

2. The free love of young men and women. 青年男女自由戀愛

Whenever young people from another village come to the village to visit friends, that evening the young men and women of the village will all

\footnotetext{
${ }^{6}$ King Pan is also known as Pangu 盤古. He is at the center of a story of the creation of heaven and earth and is not strictly speaking an historical figure. A Miao song concerning King Pan (a.k.a., Panhuang 盤皇 [Lord Pan]) is included in on pp. 6-9 of the volume and songs of this type are discussed in a later section of the book. No song about him in included in the Hainan Island volume of Compendium of Chinese Folksong, however. [Wilt: Am I right in equating these three (Pangu, Panwang, and Panhuang)? I don't have access to the later section of the book that p. 119 refers the reader to.]
} 
gather in the house of the host to sit around the stove and engage in alternate singing with the guest. There are fixed songs and unfixed songs. The contents of the fixed songs mostly concern popular love stories that are current in the regions where the ethnic Han live, such as that of Liang Shanbo 梁山伯 and Zhu Yingtai 祝英台 and of Yan Hui 嚴回 and Zhang Meng'e 張孟娥.... ${ }^{7}$

每遇有別村的青年到本村訪友時,那天晚上本村的青年男女便齊聚主 人的家裡與新到的客人圍爐對唱.歌詞有固定的與不固定的兩種.固定 歌詞的內容多是漢區流行的民間㱍愛故事,如梁祝姻緣,顏回與張孟娥 相愛等....

3. Work in the hills. 在山上勞動

When cutting wood or planting the fields in the hills, both men and women love to sing to chase away their weariness. The songs they sing then are all improvised and there are no limitations. Solo or alternate singing both occur.

在山上砍柴或種山欄時,男女都愛唱歌來驅趕疲勞; 在這裡唱的歌詞都 是隨口而出, 沒有甚麼限制, 獨唱對唱都可以. 9

What is remarkable in both of these early descriptions (Stübel's and the Social Survey's) is the emphasis on the presence of manuscripts and songs with set texts.

\footnotetext{
${ }^{7}$ A version of the second story is translated below.

${ }^{9}$ Hainandao Miaozu shehui diaocha, p. 119.
} 
The four Miao (Hmong) ballads translated below, The Song of Lü Mengzheng (Lü Mengzheng ge 吕蒙正歌), The Song of the Parrot (Yingwu ge 鵙武鳥歌), The Song of the Toad (Chanchu ge 蟾蜍歌), and Zhang Meng'e (Zhang Meng'e 張孟娥), are included in the section devoted to "Narrative Songs on Historical Legends" (Lishi chuanshuo gushi ge 歷史傳說故事歌 $)^{10}$ in the Hainan volume of the Compendium of Chinese Folksong. ${ }^{11}$ According to the information provided there, manuscripts of the first three ballads ${ }^{12}$ were provided to the collectors Pan Xian'e 潘先口 [木 radical 咢 phonetic] and Wang Renzao 王人造 in August 1985 by Deng Wen'an 鄧文安 and Qiu Yajin 邱亞金, inhabitants of the Miao 苗 village of Baishuiling 白水嶺 of Zuguan Township 祖關鎮 in the northwestern corner of Lingshui 陵水 Li Autonomous District (Lizu zizhi xian 黎族自治縣) on Hainan Island. $^{13}$

${ }^{10}$ As can be seen even from the very small sample of four ballads translated below, in terms of the content of the ballads, this category can include folktales about extraordinary parrots and "monstrous" children set in the past as well as stories that fill in, sometimes quite creatively, aspects of the lives of historical figures such as Lü Mengzheng and Yan Hui.

${ }^{11}$ Zhongguo geyao jicheng: Hainan juan 中國歌謠集成: 海南卷 (Beijing: Zhongguo ISBN zhongxin, 1997), pp. 540-545, 500-502, 503-506, and 524-25. These first three ballads are the only texts in this section which are based on manuscripts; all other narrative songs in this section are based on transcriptions of oral performances, as is the case with the fourth ballad translated below.

${ }^{12}$ Information on the provenance of the fourth ballad can be found below in the introduction to it and at the end of its translation.

${ }^{13}$ Baoting, where Yananbiao was located, is to the west of Lingshui. 
The first three ballads are actually only a small part of the rich materials provided by Deng and Qiu. Among the titles listed in the bibliography of the Hainan volume of the Compendium of Chinese Folksong, we encounter Manuscripts of Miao Folksongs and Ballads (Miaozu minge geyao shouchaoben 苗族民歌 歌謠 手抄本), identified as having been collected by Deng Wen'an and “others.”,14 This collection is said there to be over five hundred pages long, and turns out to have been one of the major sources of Miao ballads and songs for the Hainan volume of the Compendium of Chinese Folksong. We encounter two ballads from this collection in the section on "Ancient Songs/Songs on Ancient Times" (Guge 古歌), ${ }^{15}$ fourteen in the section on “Ceremonial Songs" (Yishi ge 儀式歌), ${ }^{16}$ two in the section on "Love Songs" (Qingge 情歌), ${ }^{17}$ and one in the section of "Songs on Daily Life" (Shenghuo ge 生活歌). ${ }^{18}$ Considering that the preponderance of materials selected from this work in the Hainan volume of the Compendium of Chinese Folksong classified by its editors as "Ceremonial Songs," one is tempted to believe that these manuscripts originated in the working collection of a local ritual expert of some kind, perhaps the father or other relative of Deng Wen'an,

\footnotetext{
${ }^{14}$ Zhongguo geyao jicheng: Hainan juan, p. 607.

${ }^{15}$ Zhongguo geyao jicheng: Hainan juan, pp. 31-35 and 35-37.

${ }^{16}$ Zhongguo geyao jicheng: Hainan juan, pp. 164, 164-65, 165, 165, 166, 166-68, 168-69, 179, 179, 183 $84,184,184,184$, and 185-88.

${ }^{17}$ Zhongguo geyao jicheng: Hainan juan, pp. 279 and 304.

${ }^{18}$ Zhongguo geyao jicheng: Hainan juan, pp. 408-409.
} 
whose name is always listed first in the attributions. ${ }^{19}$ The only readily available information on Deng himself appears in an appendix to the Hainan volume of the Compendium of Chinese Folksong listing the singers, recorders, and transcribers who provided material for the volume, where it is noted that he was 62 years of age in 1995, male, of the Miao minority, illiterate, and a native of Baishui Village in Zuguan Township. ${ }^{20}$

Deng Wen'an and Qiu Yajin's home village is one of the few Miao communities in Lingshui District. The predominant ethnic group in Lingshui is made up of the $\mathrm{Li}$, as one would expect from the fact that it is officially an autonomous district of the Li. The ethnic community of the Miao in Lingshui only counted 537 members in 2000 according to the local gazetteer. The same source claims that some ancestors of the current Miao communities came to Lingshui at the end of the Ming dynasty from Guangxi as soldiers mobilized by the central government to suppress one of the many rebellions of the $\mathrm{Li}$, and that others came to Lingshui some time during the Republican period. Whatever their origin, the Lingshui Miao lived in poor inland areas by the middle of the twentieth century, and only

\footnotetext{
${ }^{19}$ There are four songs, all in the "Ceremonial Song" section, in Zhongguo geyao jicheng: Hainan juan, whose attribution only mentions Deng Wen'an and not Qiu Yajin (pp. 164-65, 165, 165, and 179).

${ }^{20}$ Zhongguo geyao jicheng: Hainan juan, p. 613. The chart includes a column in which to record the profession of the people listed, but in the twelve pages of the appendix, Deng is the only one for which this column is left blank. Of the eleven names listed along with Deng for Lingshui District, two are listed as farmers (nongmin 農民) and the rest as cadre (ganbu 干部). Qiu Yajin's name does not appear in the appendix.
} 
moved to better areas in the $1950 \mathrm{~s}$ and later. ${ }^{21}$ In other areas of Hainan members of the Miao community are more numerous. Many of the Hainan Miao are fluent in Hainanese, the local variant of Minnanese, to the extent that they also use that language in their songs. ${ }^{22}$

The Hainan volume of the Compendium of Chinese Folksong does not provide any detailed descriptions of the Miao ballad manuscripts, and no page from the manuscripts is reproduced in the volume. Do these manuscripts predate the founding of the People's Republic? Or do they date from some later time? Were they copied from written sources of some kind, or written down from memory, perhaps after the end of the Cultural Revolution? All the songs and ballads from manuscripts attributed to Deng Wen'an and Qiu Yajin in Hainan volume of the Compendium of Chinese Folksong (with one exception) are written in lines of seven syllables, and employ the standard vernacular of traditional prosimetric literature in use throughout traditional China. ${ }^{23}$ That also applies to the three ballads from Deng's collection and the fourth ballad, transcribed from oral performance, translated here. ${ }^{24}$ In terms of form and language these four ballads

\footnotetext{
${ }^{21}$ Lingshui xianzhi 陵水縣志 (Lingshui District Gazeteer; Beijing: Fangzhi chubanshe, 2007), pp. 110-112.

${ }^{22}$ Zhongguo geyao jicheng: Hainan juan, pp. 3 and 7.

${ }^{23}$ Hainan Miaozu shehui diaocha, p. 120, notes that the overwhelming majority of Miao ballads employ the seven-syllable line throughout.

${ }^{24}$ Examples of typical Hainan vocabulary would appear to be extremely limited. The first item in the appendix listing common Hainanese (Hainan hua 海南話) words and phrases in Zhongguo geyao jicheng: Hainan juan, p. 620, a character composed of the “standing man radical" and chi 赤 as phonetic, occurs in the ballads (instances occur on pp. 503 and 542), but other Hainanese vocabulary cannot easily be detected.
} 
hardly show any distinctive characteristics that set them apart as "Miao ballads." Actually, the modern editors repeatedly stress that these ballads have been heavily influenced by Han-Chinese sources. The most distinctive characteristic of these three ballads may well be their four-line opening stanza, which is practically identical in each of the first three ballads, and which is claimed by the editors to be the typical introduction of popular narrative ballads of the Miao. ${ }^{25}$ The three ballads from the Deng collection translated below appear to be by far the longest texts in that collection, at least as it is reflected in the Hainan volume of the Compendium of Chinese Folksong

As the Miao in Lingshui originated from Guangxi, one possible source for their narrative ballads could have been the ballads that were printed and sold by the Qing-dynasty Sibao printers of Western Fujian who have been studied in such detail by Cynthia Brokaw. ${ }^{26}$ The Sibao printers peddled their wares in the Hakka communities of Guangdong and Guangxi, and from there these texts may also have reached the Miao communities in Guangxi. But the same ballads that were

I lack the linguistic skills to determine to what extent the (seeming) irregularities in rhyme reflect any specific dialect. It should be pointed out that local characters are more common in the ballads copied by the compilers of Hainandao Miaozu shehui diaocha.

${ }^{25}$ Zhongguo geyao jicheng: Hainan juan, p. 540. But such an opening is not found in the Miao ballads that are published on the basis of oral perfrormances. As an example of such an "oral Miao ballad," see the fourth ballad translated below. However, a somewhat comparable opening is encountered in the text of the ballad of Yan Hui and Zhang Meng'e as reproduced on pp. 122-125 of Hainan Miaozu shehui diaocha on the basis of a manuscript.

${ }^{26}$ Cynthia Brokaw, Commerce in Culture: The Sibao Book Trade in the Qing and Republican Periods (Cambridge, MA: Harvard University Asia Center, 2007), pp. 499-506. 
published in Sibao were also printed by the nineteenth-century popular publishers of Quanzhou and Zhangzhou in Southern Fujian, ${ }^{27}$ and it may have been their versions rather than those of the Sibao printers that influenced these "Miao ballads.” It is less likely that they were based on muyu shu 木魚書 from Guangdong as they are not divided into chapters and do not employ any Cantonese characters (with one possible exception ${ }^{28}$ ). As far as subject matter is concerned, the fourth ballad and two of the three Lingshui ballads (The Song of Lü Mengzheng and The Song of the Parrot) treat materials that are of HanChinese origin, but the third (The Song of the Toad) does not. Instead it narrates a story that was very popular with the Miao- but also with the Li.

\section{The Song of Lü Mengzheng}

Lü Mengzheng (946-1011) was a high official of the Song dynasty. Both his grandfather and father had been officials before him, but because his father turned both his wife and Lü Mengzheng out of the house, he and his mother lived in relative poverty during his youth. Later in life Lü Mengzheng invited both his parents to live with him, which they agreed to do, but only if they could live in separate quarters. Lü became the subject of anecdotes as early as the eleventh

\footnotetext{
${ }^{27}$ See Wilt L. Idema and Haiyan Lee, Meng Jiangnü Brings Down the Great Wall (Seattle: University of Washington Press, 2008), pp. 61-79, for the translation of a ballad that was not only printed in Sibao, but also was reprinted by the publishers of Minnanese ballads in Southern Fujian (on the Sibao edition, see pp. 270-71, note 3, and on the reprints, see p. 61).

${ }^{28}$ The Song of Lü Mengzheng once uses the character mou 友, which was apparently thought exceptional enough for the editors of the text to annotate it (Zhongguo geyao jicheng: Hainan juan, p. 541).
} 
century, but these concern either his conduct in office or predictions of his later glory. By the time he became a major character on the stage in the late thirteenth century and beyond, the emphasis had shifted to Lü's poverty in his student days and the absolute loyalty of his own wife. At least three of the most famous early $z a j u$ writers devoted a play to him, but only the play by Wang Shifu 王實甫， entitled Wind and Snow in a Dilapidated Kiln (Fengxue poyao ji 風雪破窑記) has been preserved (in a late Ming edition). ${ }^{29}$

In Wang Shifu's play, a Luoyang millionaire surnamed Liu seeks a groom for his daughter, Liu Yue'e 劉月娥, by allowing her to toss an embroidered ball into a crowd of suitors. When the ball is caught by the dirt-poor student Lü Mengzheng, and his daughter refuses to repudiate the match, her father orders her to leave the house. The couple lives in a dilapidated kiln (or cave house), and they are so poor that Lü each day joins the monks of the famous Baima si 白馬寺 (White Horse Temple) to share their noon-time meal, until the angered monks toll the bell announcing the meal only after they have finished eating, leaving nothing for Lü. Later Lü departs to take part in the civil service examinations, making use of some money that a friend tells him he has been given by an anonymous donor. When Lü returns ten years later as magistrate of Luoyang, he first tests the loyalty of his wife by claiming he is still a poor student, and only tells her of his rise to power once he has discovered that she has remained faithful to him for all these

\footnotetext{
${ }^{29}$ The official career, the early anecdotes, and the Yuan and Ming dramatic adaptations have been studied in great detail in C.K. Wang, "Lü Meng-cheng in Yüan and Ming Drama," Monumenta Serica 36 (198485): $303-408$.
} 
years despite her poverty. In the final act of the play, Lü learns that his father-inlaw had not only told the monks to shame him but also had been the anonymous donor of the money that enabled him to sit for the exams, and the plays ends with a grand reunion. The play shares its basic plot (the deliberate frustration of a talented and poor student in order to spur him on to greater effort, and his final success and reunion with his benefactors) with at least five other early zaju, as has been pointed out by C.K. Wang. ${ }^{30}$ The same scholar also has studied such conventional plot element as the marriage by throwing a ball into a crowd of suitors, ${ }^{31}$ and the test of the faithful wife by her husband following his long absence. $^{32}$

The plot was further developed in the chuanqi versions of the Ming dynasty, commonly known as The Bunted Loft (Cailou ji 彩樓記). The young couple is now robbed of her wedding gifts by an evil inn-keeper when they are traveling to the abandoned kiln where Lü lives. When later her parents send them some rice and money, Lü suspects his wife of having obtained these riches by improper means. The play would remain a popular item in the repertoire of many genres of local opera, and the story was also adapted in many genres of local prosimetrical storytelling.

\footnotetext{
${ }^{30}$ C.K. Wang, "Lü Meng-cheng in Yüan and Ming Drama," pp. 346-47. See also Wilt L. Idema, "Educational Frustration, Shape-Shifting Texts, and the Abiding Power of Anthologies: Three Versions of Wang Can Ascends the Tower," Early Medieval China 10-11 (Part Two) (2005): 150-53.

${ }^{31}$ C.K. Wang, "Lü Meng-cheng in Yüan and Ming Drama," 341-45.

${ }^{32}$ C.K. Wang, "Lü Meng-cheng in Yüan and Ming Drama," 347-48.
} 
The first part of The Song of Lü Mengzheng basically provides a very simplified account of the legend as presented in chuanqi plays, but the second part of the text includes some scenes (Lü's humiliation by two butchers; Lü’s experiences while traveling to the capital; and Lü's treatment at the hands of the innkeeper in the capital) which do not have a counterpart in these Ming plays. More research is needed to locate the possible sources of these episodes.

\section{The Song of the Parrot}

The Song of the Parrot is an adaptation of the tale of the young parrot that lands in trouble because of its flippant loquaciousness. When the captured bird eventually has charmed the emperor with its poetic talents and has been set free, it discovers that in the meantime its mother has passed away, and it is aided by the other birds to provide her with a proper funeral. In many versions of the legend it then joins Guanyin as one of her disciples. The earliest and most complicated telling of this legend is encountered among the cihua 詞話 that were printed during the Chenghua period (1465-1487) of the Ming dynasty, but may well date from an earlier period. ${ }^{33}$ That adaptation highlights the filial nature of the parrot in its title, which reads The Parrot's Filial Piety (Yingge xiaoyi zhuan 鶯哥孝義 傳). ${ }^{34}$

\footnotetext{
${ }^{33}$ See Anne E. McLaren, Chinese Popular Culture and Ming Chantefables (Leiden: Brill, 1998), for a detailed discussion of the discovery of these texts in 1967 and the cihua genre.

${ }^{34}$ On the background of this text, see Wilt L. Idema, "Guanyin's Parrot, A Chinese Animal Tale and its International Context," in Alfredo Cadonna, ed., India, Tibet, China: Genesis and Aspects of Traditional
} 
The legend continued to circulate in later centuries. Probably the best known of these retellings is the anonymous Precious Scroll of the Parrot (Yingge baojuan 鸣哥寶卷), which has been preserved in a number of Qing and Republican editions, and which imposes a clear sectarian message on the story. ${ }^{35}$ A quite different version, still a precious scroll but without any sectarian coloring, circulated under the same title in Western Gansu in the $20^{\text {th }}$ century. A potted version of the legend was also included in the Precious Scroll of Good-in-Talents and Dragon Daughter (Shancai Longnü baojuan 善才龍女寶卷). ${ }^{36}$ The parrot in The Song of the Parrot still provides its mother with a proper burial with the help

Narrative (Firenze: Leo S. Olschi Editore, 1999), pp. 103-150. For a full Dutch translation of this text, see Wilt L. Idema, Prinses Miaoshan en andere Chinese legenden van Guanyin, de bodhisattva van barmhartigheid (Amsterdam: Atlas, 2000), pp. 235-68. The parrot in Chinese culture of the first millennium has been studied by Edward H. Schafer, "Parrots in Medieval China," in Søren Egerod and Else Glahn, eds. Studia Serica Bernhard Karlgren Dedicata (Kopenhagen: Ejnar Maunksgaard, 1959), pp. 27182. Native Chinese parrots (a kind of green parakeet) came from Longxi, the inaccessible mountains of Eastern Gansu, but had been hunted to extinction by the beginning of the second millennium. The white parrot, a favorite of Tang aristocrats, was an exotic import from the area of modern-day eastern Indonesia and New Guinea, but it is not clear to what extent these "white parrots" were always true parrots. See Roderich Ptak, “"Weisse Papagaien” (bai yingwu) in frühen chinesischen Quellen bis zu der Tang-Zeit," in Roderich Ptak, ed., Tiere in alten China: Studien zur Kulturgeschichte. Maritime Asia 20 (Wiesbaden: Harrasowitz Verlag, 2009), pp. 31-48.

${ }^{35}$ Wilt L. Idema, "The Filial Parrot in Qing Dynasty Dress: A Short Discussion of the Yingge baojuan [Precious Scroll of the Parrot]," Journal of Chinese Religions 30 (2002): 77-96.

${ }^{36}$ For a full translation of this text, see Wilt L. Idema, Personal Salvation and Filial Piety: Two Precious Scroll Narratives of Guanyin and her Acolytes (Honolulu: University of Hawai'i Press, 2008), pp. 161-89. 
of other birds (and beasts), but its filial piety is not otherwise stressed. It also does not join Guanyin as an acolyte in the end, but returns to the imperial court. But whereas in some other versions the parrot is allowed to have its revenge on the persons responsible for taking it from its mother, in this version it fails to exact revenge on the student who caused its capture - the student is actually rewarded with a nice job by a grateful emperor.

The Song of the Toad

The Song of the Toad provides us with yet another version of the tale of the princess and the frog. This story is probably best known from the Grimms' fairy tales - it provides the opening tale of their Kinder- und Hausmärchen. In the recent update of the Aarne-Thompson index by Hans-Jörg Uhta as The Types of International Folktales: A Classification and Bibliography Based on the System of Antii Aarne and Stith Thompson of 2004, the stories of this type still are classified as No. 440, "The Frog King or Iron Henry."37 Older studies often argued that this story-type was limited to North-Western Europe, but more recent studies have identified examples from almost every part of the globe. ${ }^{38}$ Ting Nai-tung has listed examples from China in his A Type Index of Chinese Folktales in the Oral

\footnotetext{
${ }^{37}$ Hans-Jörg Uhta, The Types of International Folktales: A Classification and Bibliography Based on the System of Antii Aarne and Stith Thompson (Helsinki: Suomalainen Tiedeakatemia, 2004), pp. 262-63.

${ }^{38}$ Strangely enough, examples from South Asia would appear to be extremely rare, even though some villages in India will celebrate a wedding of a frog and a young girl during times of drought, as was reported by the Times of India of January 17, 2009.
} 
Tradition and Major Works of Non-Religious Classical Literature (1978), ${ }^{39}$ but Lutz Röhrich has questioned whether the stories listed by Ting as examples of AT 440 really qualify. Whereas in the European stories listed under AT 440 the story is told from the perspective of the princess, in these stories the tale is told from the perspective of the enchanted animal, the future groom. ${ }^{40}$ Even though the main characters are a princess and a frog (or toad), the stories show structurally a clear similarity to the stories classified as AT 441 ("Hans My Hedgehog”), as the story follows the adventures of a boy who is born as a small animal, saves the king from disaster, marries his daughter, and is turned into a handsome young man. $^{41}$

While the frog and toad occupy a very modest position in the tales of the HanChinese, they play a very prominent part in the rituals and myths of various southern ethnic groups such as the Zhuang, who celebrate a ritual wedding of a frog-bride and a human groom. ${ }^{42}$ Many Zhuang and Miao stories tell of childless couples that have a frog-son after they have prayed to the gods for an heir. A story

\footnotetext{
${ }^{39}$ Ting Nai-tung, A Type Index of Chinese Folktales in the Oral Tradition and Major Works of NonReligious Classical Literature (Helsinki: Suomalainen Tiedeakatemia, 1978). This work was translated into Chinese as Ding Naitong 丁乃通, Zhongguo minjian gushi leixing suoyin 中国民间故事类型索引 (Wuhan: Huazhong shifan daxue, 2008).

${ }^{40}$ Lutz Röhrich, "Der Froschkönig," in Wilhelm Solms, ed., Das selbstverständliche Wunder: Beiträge germanistischer Märchenforschung (Marburg: Hitzeroh, 1986), pp. 7-41, esp. p. 16.

${ }^{41}$ Hans-Jörg Uhta, The Types of International Folktales, p. 263.

${ }^{42}$ Lubica Obuchová, "Frog and Toad Symbols in Zhuang Folklore (Southern China)," Archiv Orientální 67 (1999): 257-78.
} 
of a toad that defeats the enemy of the land and ends up marrying the daughter of the king was recorded in Guangxi as early as $1930,{ }^{43}$ but the story was also extremely popular on Hainan Island. As we will see, the editors of The Song of the Toad in Hainan volume of the Compendium of Chinese Folksong note that the story was not only very popular among the Miao on Hainan, but also with the Li, even though they still had not discovered a Li ballad on this theme. ${ }^{44}$

\section{Zhang Meng'e}

On various websites Zhang Meng'e is praised as one of the most popular ballads among the Miao of Hainan. The song circulated in at least two forms, one as straight narrative and one as a series of questions and answers. Its main characters are the beautiful maiden Zhang Meng'e and the young man Yan Hui. Yan Hui is, of course, well known as the favorite disciple of Confucius who died young and in poverty. While the Yan Hui of this Miao ballad still dies at an early age, he definitely is not poor anymore-it now takes three hundred carriers to carry the engagement gifts for his bride-to-be Zhang Meng'e. If Yan Hui was the embodiment of all Confucian values, his fiancée shows the same moral mettle, and she becomes a "chaste maiden" upon his death. In this respect the song reflects the Chinese cult of chastity of the Ming and Qing dynasties, as pointed out by the editors of the Hainan volume of the Compendium of Chinese

\footnotetext{
${ }^{43}$ Lubica Obuchová, "Frog and Toad Symbols in Zhuang Folklore (Southern China)," pp. 270-71.

${ }^{44}$ Zhongguo geyao jicheng: Hainan juan p. 506.
} 
Folksong. ${ }^{45}$ On the other hand, this ballad is the only one of the four translated here in which the word Miao occurs (see both the beginning and end of the ballad).

The version translated below was transcribed from an oral performance of it in the Miao Village in one of the inland townships of Changjiang, a Li autonomous district on the southwesterly side of Hainan Island. The local gazetteer for Changjiang claims that the Miao are one of the major ethnic groups in the district along with the Han and the $\mathrm{Li}^{46}$ but it turns out that the number of Miao in Changjiang is actually very small—in the census of 1990 there were only 160 Miao in a total population of over 200,000 people. $^{47}$ The performer of the ballad is described, in the appendix listing the singers, recorders, and transcribers referenced above, as a male member of the Miao minority, 22 years old in 1995, possessing a junior high- school education, and a farmer by occupation. ${ }^{48}$ This

\footnotetext{
${ }^{45}$ Zhongguo geyao jicheng Hainan juan, p. 525. A translation of their comments follows the translation of the ballad below. For a detailed study of the chaste maiden cult, see Weijing Lu, True to her Word: The Faithful Maiden Cult in Late Imperial China (Stanford: Stanford University Press, 2008). In the version of the ballad of Yan Hui and Zhang Meng'e that is included in Hainandao Miaozu shehui diaocha p. 122-125 Zhang meng'e eventually commits suicide.

${ }^{46}$ Changjiang xianzhi 昌江縣志 (Beijing: Xinhua chubanshe, 1998), p. 127. The Han are by far the largest ethnicity in Changjiang; the Li make up only one quarter to one third of the population.

${ }^{47}$ Changjiang xianzhi, p. 128. From the one paragraph description of the Miao on p. 810 we learn that the current Miao population of Changjiang moved into the district in the Republican period, and they were settled in Chicha 七差 Township in 1976. Chicha Township is where Zhang Meng'e was recorded. [I added this last sentence]

${ }^{48}$ Zhongguo geyao jicheng Hainan juan, p. 618.
} 
ballad is included for both the inherent interest of its content and for comparison with the other three ballads, which were copied from manuscripts. Even in translation, the reader will be struck by the heavier use of repetition and formulas in this ballad, as compared to the other three.

\section{The Translations}

As in my other translations of Chinese verse narrative I usually translate one line of verse in the original by one line of verse in English. Since all the lines of the original have precisely the same length, I have tried to imitate this in my translations by giving each line in them roughly the same length, but I have only been partially successful in this attempt. I have not tried to impose rhyme or a specific metrical pattern on my translations. In general the original texts do not present that many problems of interpretation, and the editors of the Hainan volume of the Compendium of Chinese Folksong have provided a modest number of annotations. Still, I have found a number of passages, especially in the Song of Lü Mengzheng, were the narrative is not as clear as one would wish. As in all forms of ballad, the text may switch from third-person narrative to direct discourse at any time. Such switches would be immediately clear in performance. When translating on the basis of a bare text, it is up to the translator to be alert to such switches. I have also included in my translations the additional information provided by the editors of the Hainan volume at the end of each text. 
The Song of Lü Mengzheng

(Seven-syllable tune)

The Pure Pond from ancient times tells stories,

So let me sing an ancient tale for a while.

Before I sing of formers kings and queens,

I first will sing the song of Lü Mengzheng.

When the sun emerges from Fusang ${ }^{49}$ the sky turns red;

The golden rooster announces dawn in the fifth watch.

The golden crow $^{50}$ day and night continues to roll on,

Sinking in the west at night, emerging in the morning.

As mist and dew covers the hills, I sing of Mengzheng:

From the moment of his birth, his family was destitute.

Above he had no elder brother, below no younger brother,

And his uncles' families were all completely destitute.

When his clothes were worn and tattered, no one cared,

Everyday he wandered about, living a life of misery.

\footnotetext{
${ }^{49}$ The Fusang (supporting mulberry tree) grows at the eastern edge of the world.

${ }^{50}$ According to traditional Chinese mythology, the sun is inhabited by a three-legged crow.
} 
While on the road he ran into a traveling soothsayer,

Who displayed a banner claiming to know the future.

Mengzheng informed the master of his date of birth:

"Master, now figure out my fate and tell me the truth!"

Using paper and brush he arranged the eight characters: ${ }^{51}$

Lü's head carried the Kuixing Star, ${ }^{52}$ his eyes the bow.

"The eyes carry the bow, the hour carries the arrow:

Study the books and most likely you'll be a minister!"

When Mengzheng had been informed of this prediction,

He turned around, entered the school, studied the books.

Because he was poor, he tightened the belt of his pants;

When the sun sank behind the hills, his house was dark.

In the third watch of the night he had three dreams,

And he saw a pig's bladder shine with great brightness.

So when he got up the next morning at an early hour,

He eagerly awaited the arrival of a divine immortal.

A butcher came and brought him the bladder of a pig;

He had made a hole in it so he could fill it with fireflies, And he captured and put in it fireflies without number, At dusk the light produced was like a red and glaring fire. ${ }^{53}$

\footnotetext{
${ }^{51}$ The "eight characters" are the four two-character combinations recording the year, month, day, and hour of birth, which are widely used in prognostication.

52 The Kuixing star determines success in the official examinations. The following references to "the bow" and "the arrow" are unclear to me.
} 
His study was brightly lit until well into the fifth watch,

With greatest devotion he continued to read his books. ${ }^{54}$

He memorized the millions of scrolls of the Classics,

Till each single line of the texts was stored in his belly.

The other students that strolled through the academy

Each day at dawn would go off to the east or the west.

But he was dressed in an unlined shirt and lacked food,

And day and night he pondered, lamenting his poverty.

His hand was never far from his one bamboo stick,

Only a thin gown and bamboo hat against the cold wind.

That year a placard was posted summoning gentlemen

To take part in the examinations for high appointment.

The richest man in town's Third Daughter had a dream:

A royal dragon appeared from the pillar on the east.

A royal dragon at night promises great prosperity,

But a royal dragon seen at daytime spells destitution!

The next morning, when she had gotten up very early, She set out a large banquet, laid out a full spread,

${ }^{53}$ CheYin 車胤 is said to have studied at night by the light of fireflies he had collected in a sack of white silk.

${ }^{54}$ Literarly: "With greatest devotion he recited his books, hanging them from the horns." This is an allusion to the story of Li Mi 李密 of the Sui dynasty, who was so devoted to study that when herding an ox he would read one book while riding the animal and hang other books from its horns. 
And invited all of the literate "flourishing talents," 55

Whether or not they were loaded with money or poor.

Those who arrived first had a place to sit down,

Dressed in silk and gauze they proclaimed their fame.

Having been assigned their seat, they all sat on chairs,

And were treated to dishes piled up with fish and meat.

Mengzheng arrived late--there wasn't even a bench;

He sat down on the base of a pillar on the eastern side.

He found a small table and a small bench to sit on,

And rotten fish and left-over meat filled his plate.

The satin cap on his head was all worn and tattered;

His gown and his shift had been patched with grass-cloth;

His old shoes exposed his toes to the southern winds.

Raising his chopsticks Mengzheng ate with lowered head;

Third Daughter, about to throw the ball, ${ }^{56}$ saw no dragon,

But Mengzheng's feet showed as those of a dragon,

And like dragon or tiger he devoured the food on his plate. ${ }^{57}$

\footnotetext{
55 "Flourishing talent" (xiucai 秀才) was the title of those who had passed the lowest examinations, at the prefectural level.

${ }^{56}$ In traditional narratives, young women often select a groom by throwing an embroidered ball from a bunted loft into a crowd of suitors - the man who catches the ball will become her husband. There is no evidence that this was ever an actual wedding custom. See C.K Wang, "Lü Meng-cheng in Yüan and Ming Drama," pp. 342-45.
} 
Third Daughter looked down from her upper-story room,

Wondering who of them might be the true royal dragon.

Third Daughter then remembered her midnight dream:

The grass-clothed one by the pillar was the royal dragon!

Third Daughter threw the ball right at Mengzheng,

When Mengzheng had caught it, his face turned red.

All those others clapped their hands, laughing loudly:

"Rejecting those of wealth and status she chooses a pauper!"

Third Daughter answered those present by saying:

“All who are present, please listen to my explanation.

It's not in my fate to marry a man who has high status,

Heaven has determined that I will suffer destitution.”

Her father loudly cursed her for lacking filial piety:

"How can you follow Mengzheng to his abandoned kiln?"

Third Daughter promptly replied to her father, saying:

"I don't care whether he is loaded with money or not!

My father, you may be filled with regret but I am not.

People outside on the street will judge my filial piety.

If Heaven determines I'll be rich, then I will be rich;

\footnotetext{
${ }^{57}$ In popular Chinese narrative persons who are down and out on their luck may shown sings of their future greatness to those who are destined to see and understand those signs. A dragon, however, is usually the sign manifested by a future emperor, not by a future minister.
} 
If Heaven determines I'll be poor, then I will be poor."

The richest man in town now was overcome by rage, He chased her out of the house and then closed the gate. Third Daughter did not blame or reproach her parents, But set out with Mengzheng for his abandoned kiln.

Mengzheng carried Third Daughter's boxes and baskets

As the sun was slowly sinking behind the western hills. Even though the road to his hometown was not that far, They still feared they might run into robbers on the road.

So they stayed at Granny Huang's inn for that night:

The Dark Dragon Prince ${ }^{58}$ stayed for the night at an inn.

The boxes were filled with gold and silver jewelry,

When Granny Huang saw this, her pupils turned red. ${ }^{59}$

Granny Huang eagerly offered the couple some wine,

Cup upon cup she offered to this totally destitute man.

Mengzheng drunk the wine until he was drunk as a skunk,

\footnotetext{
${ }^{58}$ Lü Mengzheng. Original Dragon (Yuanlong 元龍) was the style of Chen Deng 陳登 of the early third century, but it is not quite clear why the text here would allude to this figure. In the Qing dynasty, the character yuan 元 was used to substitute for the character 玄 (xuan; dark, hidden), which was taboo because it was part of the personal name of the Kangxi emperor. If our manuscript is (based on) a Qing text, the original text may have been xuanlong (dark dragon, hidden dragon), describing Lü Mengzheng during his years of adversity.

${ }^{59}$ Because of greed.
} 
Husband and wife lay down and slipped into a dream.

Granny Huang became a robber and stole their boxes,

She ran off with the jewelry and all the gold and silver.

When Mengzheng woke up, boxes and baskets were gone,

And husband and wife silently pondered their situation:

"When your roof is leaking, it will rain for days on end;

When the rice spouts just emerge, they will suffer frost.

If a chain bucket catches a fish, a wild dog will steal it,

And if one tiger has left, yet another tiger will show up!"

How can it be said that he achieved wealth by marrying a wife:

The baskets were stolen and he was as poor as before!

Mengzheng brought his wife with him to his abandoned kiln:

His house was only four walls, there was nothing inside!

The one broken pot was also covered by a broken lid;

Instead of a bucket to fetch water he used a bamboo tube.

The swept floor served as bed-leaves served as mattress;

When it was cold they collected straw against the wind!

There was no gate and no door that could be closed,

They wove a mat of bamboo splints to keep out the wind.

Third Daughter day and night always wanted to weep,

She thought the days impossible, the nights interminable! 
How she hated the Registrar ${ }^{60}$ for the fate she suffered,

The embroidered ball had thrown her into dire poverty.

Mengzheng answered his worthy wife in these words:

"It was your choice to abandon wealth and love poverty!

You wanted to become my wife when you threw the ball:

If this doesn't suit you, it's not that I forced you to it.

A soothsayer once told me I would become an official;

When it is time and my luck turns, prosperity will come.

Cursing Heaven and Earth will not help get what you want-

When cooking in a big pot, you have to be patient.",61

Third Daughter answered her husband as follows:

"You should not lock up your heart inside your belly.

I am made of pure gold that isn't afraid of the fire;

Wild ghosts do not enter a broken-down dwelling!"

Mengzheng then left the house on some business,

And Third Daughter stayed home, loudly weeping.

She complained that no one pitied her misfortune,

That she had no one to inform her father and mother.

\footnotetext{
${ }^{60}$ The underworld official in charge of the registers of life and death in which the fate of each person is inscribed.

${ }^{61}$ The intended meaning of this sentence probably is that if you have big plans, you have to bide your time, just as when you are cooking in a big pot you have to be patient because it will take longer before everything is cooked well.
} 
Fortunately a family servant transmitted her words,

Telling them their own daughter was living in a hovel.

When one's darling ${ }^{62}$ grows an ulcer, a parent is pained,

So her mother told the servant to bring her some rice.

When Third Daughter saw that the servant had arrived,

She resembled a thirsty person finally finding water.

When evening fell, Mengzheng came back home again,

And when he saw this situation, his thoughts were heavy.

His mind was filled with a regret that was without end,

And without saying a word, he pounded his breast.

When Third Daughter saw this, she asked Mengzheng:

"What is bothering you so you're pounding your breast?

If you have something on your mind, tell it to my face:

A stupid stone ${ }^{63}$ when hammered well will get the message."

Mengzheng then berated his wife for looking for trouble:

"Why did you insist on marrying someone who lives in a kiln?"

Third Daughter stepped forward, fell down on her knees,

Urging her husband to show some more understanding:

“Don't cut yourself off from me by these words you speak!

My mother sent me this rice and also sent me this silver.

\footnotetext{
${ }^{62}$ Literally “pig's liver" (zhugan 猪肝). From the context I guess the expression has the same meaning as xingan 心肝 (heart and liver; darling).

63 “A stupid stone" (wanshi 頑石) is a common simile for an unenlightened human being.
} 
The rice white like snow is stored in these earthen jars;

Each and every ingot of silver is covered by grubs. ${ }^{64}$

If our fate is vile, we'll wander and seek but a decent death;

If our fate is poor, we'll separate and be buried apart.

If we are lucky, we need not fear our family being poor-

Even if one has money, one cannot buy long life!"

When Mengzheng heard her speak in this manner,

He devoted himself to his studies without any worry.

He read through the millions of scrolls of the Classics

And memorized each and every line of their texts.

That year a placard was posted announcing exams,

Mengzheng prepared a rice sack to carry on his shoulders. ${ }^{65}$

Just as he was ready to leave and set out on the road,

The river couldn't be crossed because of a big flood.

He went to the butchers to buy a pound of pork on credit,

To take home and make a vow, praying to the gods.

There were two butchers--one let him buy on credit,

So carrying the meat he returned to his abandoned kiln.

Third Daughter took it from him to cook it in a pot,

And the fire started burning with brightly red glare!

\footnotetext{
${ }^{64}$ I take this to mean that Third Daughter never has touched the silver she received from her parents.

${ }^{65}$ A special type of sack: two sacks joined at the bottom for ease in carrying the sacks over one's shoulder.
} 
The other butcher of the two became very angry:

"You should've known that Mengzheng is destitute!

Now you have sold Mengzheng some pork on credit,

We will never see half a penny in a thousand years!"

That other butcher answered him in these words:

"How should I know whether he has money or not?"

As fast as he could he came to Mengzheng's hovel,

And said: "If you have any cash, then pay in cash!

If you don't have cash, give the pork back to daddy!"

Mengzheng didn't have the cash but didn't dare say so,

And he answered him in the friendliest way possible.

[But the butcher replied:] "Catch a flea if you find one!

If you don't have cash, give the pork back to daddy!"

After the butcher had taken his pork and left again,

Husband and wife were awash in tears without end,

And the tears they shed served them as their bouillon:

Now even the immortals knew of Mengzheng's poverty!

The immortals ascended to heaven and told the Jade Emperor:

"Down on earth the poorest person is Mengzheng!"

The Jade Emperor replied to the divine immortals:

"Mengzheng is destined to become a Top-of-the-List. 
It will taken ten more years for him to pay his debt, ${ }^{66}$ And then he will be proclaimed the Top-of-the-List." The divine immortals addressed the Jade Emperor:

"After another ten years he will have died of poverty!

It's far better to allow him to pass the examinations

And to rise to the position of minister this very year!"

Mengzheng set out on the road, carrying his luggage, All by himself he walked on till he reached the boat.

He saw the boat, with too many passengers, was rocking!

On the boat every gentleman had brought a servant.

The cabin of the boat was stuffed with their luggage.

Mengzheng addressed these gentlemen as follows:

"When water enters from the bow, it can't be stopped;

Make sure that your writings don't end up in the water."

These gentlemen did not listen to Mengzheng's advice,

Unconcerned their writings might end up in the water.

Mengzheng addressed these gentlemen once again:

"Gentlemen, please let me tell what the situation is,

I carry my own luggage while traveling on the road,

So I don't have to bring a servant with me to the exams."

When these gentlemen heard him speak in this way,

\footnotetext{
${ }^{66}$ The karmic debt caused by sins in a prior life.
} 
They all concluded that his words did make sense,

So they all ordered their servants to go back home

And made room for Mengzheng's two sacks of rice.

When they arrived at the capital city, they sought an inn,

Throughout the inn their beddings were splendidly red!

At night they spread out their bedding and went to sleep--

Mengzheng, without bedding, slept in the chicken coop. ${ }^{67}$

At midnight the innkeeper had a dream, and in that dream

A royal dragon emerged from the pillars of his house.

Early next morning he woke up and rose before dawn

In order to see who was sleeping in his chicken coop.

"All the eggs in this chicken coop have been stolen,

And it is you, Sir, who must have stolen these eggs!

One chicken egg has the price of one penny of cash--

I don't care whether you're loaded with money or not!"

When Mengzheng heard the innkeeper's speak this way,

He said: "Having no bedding I slept in the chicken coop."

All the while the innkeeper of course knew quite well

That this man was destined to be the Top-of-the-List.

The other gentlemen wanted to pay for the eggs,

\footnotetext{
${ }^{67}$ This may seem an unlikely place, but in eighteenth-century Beijing the poorest of the poor spend the night in sheds filled with chicken feathers.
} 
And they explained that Mengzheng was destitute.

The innkeeper then said with a smile to Mengzheng:

"I am not concerned about the few coppers for those eggs.

I'll give you a silken gown so you'll have one to wear;

That grass-cloth gown and torn shirt can go in your luggage."

Mengzheng answered the innkeeper in these words:

"If I have to wear hemp I won't begrudge my poverty,

If you plant hemp it can be woven into linen,

I pity those poor other people who feel ill at ease."

The innkeeper answered Mengzheng in this way:

"Now, Sir, please listen to the words I have to say.

If you pass the examinations, I will come for these;

If you don't pass the exams, I won't want them--

My gift and my capital will go down the drain!"

The other gentlemen uniformly urged Mengzheng,

To put on those two items made of finest silk:

"Tomorrow we rise early to enter the examination grounds

Where it all will come down to the texts of our essays!"

That night at midnight the emperor had a dream:

The two gates of the palace were brilliantly red!

The next morning he rose up at the break of dawn, And in the palace hall the emperor told his dream. 
He promptly ordered a scholar to explain his dream,

That specialist explained his dream, holding nothing back:

"The two openings connected are the character ' $\mathrm{Lü},{ }^{6}{ }^{68}$

The Top-of-the-List clearly has entered the palace!"

When the emperor had heard the master's words,

He secretly remembered them in his own heart.

Fourth quarter of the third watch: the drum resounded,

And Mengzheng entered the Golden Bells Palace.

When the emperor entered the hall in the fifth watch,

Gongs and drums shook the heavens with their din!

Mengzheng was listed at the head of the golden list:

One dot of the vermillion brush, and he's Top-of-the-List!

Official hairpins fastening his cap, he expressed his thanks;

Out in the streets his horse wore a bright red decoration.

All streets were swept clean for him by the sweepers;

The message from the capital traveled fast as the wind.

Mengzheng remembered the events from his past,

All those many affairs floated through his brain.

Firstly he remembered how Third Daughter entered the kiln, And because of their poverty suffered starvation and distress.

Secondly he remembered the bell of the monastery:

\footnotetext{
${ }^{68}$ The character Lü 呂 is made up of two characters kou $\square$ (mouth, opening, entrance).
} 
The monks sounded the bell when they had their meal.

But these evil monks came up with a devious plan:

They first had their meal and then sounded the bell!

So when Mengzheng arrived at the temple's gate,

Everyone clapped their hands and laughed at him.

One friendly monk then taught him this sentence:

"If you don't find it here, you will find it there."

Mengzheng lowered his head, didn't dare to speak,

But he wrote this quatrain on a wall of the temple:

Every day I ate the rice distributed to the community,

But today the bell was sounded following the meal.

If I, Mengzheng, am ever listed on the golden roster,

There will come a day my enemies and I will meet. ${ }^{69}$

Thirdly he remembered the inn of Granny Huang,

Where the pearls and other jewelry had been stolen.

May those boxes and baskets filled with fine clothes,

Beat your very bones to powder and dust!

By accident he ran into the butchers on the street:

"I do remember how empty my pot was in those days!

But now we are met again here in the street,

\footnotetext{
${ }^{69}$ In the more common version of this anecdote, the poor Lü Mengzheng first writes two line of verse on the walls of the Baima si in Luoyang when he has been shamed by the monks, and completes the poem many years later when he has reached a high position. See C.K. Wang, "Lü Mengzheng in Yüan and Ming Drama," pp. 345-46.
} 
And it is better to forgive others, when one can."

In the beginning Mengzheng lived in humble poverty;

This day he has become His Excellency Top-of-the-List.

Let me exhort you all, men and women of this world:

When wife is virtuous and husband honored that is true success!

Mengzheng was destitute but became rich and noble,

Later, pitying the poverty of his poor country relations,

He bought the finest delicacies and feasted his neighbors,

And during the banquet provided them with advice.

I've sung to the end the ancient tale of Lü Mengzheng,

Who left a fragrant reputation for generations to come.

Manuscript provided by Deng Wen'an and Qiu Yajin.

Collected by Pan Xian'e and Wang Renzao.

Collected in August 1985 in the Miao village of Baishuiling of Zuguan Township in Lingshui District.

Additional note: Many of the long narrative songs that circulate among the Miao people are legends and tales that have been adopted and inherited from the Han people. This 
song teaches people to understand the great principles and to establish a lofty and noble character that when in poverty cannot be robbed of its ambition, and that once rich and noble does not lose its original goodness. That it has been sung and transmitted among the Miao for a long time, and that a manuscript has been transmitted, makes it clear that this song's influence among the Miao is undeniable. 
The Song of the Parrot

(seven-syllable tune)

The Pure Pond from ancient times tells stories,

So let me sing an ancient tale for a while.

Before I sing of former kings and queens,

I'll tell you all about the parrot and its origin.

In Guangnan lived a student with the surname of $\mathrm{Di}^{70}$

Intelligent, he was fully conversant with the Five Classics.

With his servant he went to the capital to sit for the exams,

The main examiner Jin Gui was wearing a gown of gauze.

But when the red list was displayed, it lacked his name;

Suffering in silence he thereupon returned to his village.

When he arrived, returning, at the foot of Mt. Longxi,

He rested under a green pine tree to enjoy its cool shade.

On that mountain there also lived a bird called the parrot,

Flying it came to the tree and rested on a high branch. ${ }^{71}$

\footnotetext{
${ }^{70}$ The character 帝 ( $d i$; emperor) is not attested as a surname. It may be a mistake for 狄 ( $\left.d i\right)$.
} 
In the tree the parrot recited a poem cursing the student:

"Student, you studied the Five Classics all to no avail!

After three years of exams, you still have not passed:

No need to feed such an idle fellow with unearned food!"

Cursed like this, the student did not know what to say,

He concluded he only could suffer these taunts in silence.

He would not go back home to his father and mother,

But return to the capital to tell the emperor [of the parrot].

The student reported to His Majesty the Emperor, saying:

"The parrot on the southern mountain can recite poems!"

As soon as the emperor had learned this information,

He ordered all counties and districts to catch the parrot.

The mountain people everywhere were all mobilized

To catch the parrot on Mt. Longxi's southern mountain.

On each and every mountaintop bird nets were spread,

Making it impossible for the parrot to fly off into the sky! ${ }^{72}$

As it flew off into the sky, the parrot was caught in a net;

The ones to ask for merit and a reward were the officials.

\footnotetext{
${ }^{71}$ For Longxi (the hills of eastern Gansu) as the home of the native Chinese parrot, see Edward H. Schafer, "Parrots in Medieval China," pp. 271-82.

${ }^{72}$ The hunt for parrots in Longxi is the subject of a poem by the Tang poet Pi Rixiu 皮日休 (ca. 834-ca.883) entitled “Ai Longming” 哀隴敏. See Pi Rixiu, Pizi wensou 皮子文藪 (Shanghai: Shanghai guji chubanshe, 1981), p. 111. For English translations, see Edward H. Schafer, "Parrots in Medieval China," 273-274, and Wilt L. Idema, “Guanyin's Parrot, A Chinese Animal Tale and its International Context,” p.126.
} 
Once they had caught the parrot and locked it in a cage, They took him to the court to the sound of gongs and drums!

The court officials reported the parrot's arrival at court, When the emperor saw it his joy knew no bounds.

The emperor immediately made the following promise:

"They tell me that you, parrot, are able to recite poems.

If you don't recite any poem for me, to hear,

You will be killed and flayed, according to the law."

As soon as the parrot heard the emperor talk in this way,

It promptly, flapping its wings, recited the following poem:

"Firstly I wish that Our Emperor may live ten thousand years,

Secondly I wish that all-under-heaven may enjoy Great Peace.

Thirdly I wish that Mt. Tai will not house any robbers,

Fourthly I wish that the empress may give birth to a boy.

Fifthly I wish that the great rite ${ }^{73}$ may be executed each year,

Sixthly I wish that your noble sons may wear dragon robes.

Seventhly I wish that the winds and rains may come timely,

Eighthly I wish that the mynah may long for its branch.

Ninthly I wish that that student may pass away quickly,

Tenthly I wish that this dead trunk may sprout branches again."

The emperor clapped in his hands and laughed heartily,

\footnotetext{
${ }^{73}$ The "great rite" probably refers to the Suburban Sacrifice to Heaven.
} 
As he saw that this parrot was really a wonderful bird!

He appointed the student to an official position in which he,

On horseback, carrying a seal, was in charge of the people!

A document was dispatched to all counties and districts

That the people had to catch insects to feed the parrot.

The parrot had been caught and was locked in a cage,

In its cage it felt lonely, and it was filled with sorrow.

So the parrot recited a poem to inform the emperor:

"May you live a myriad years, till your destined time!

Ever since that student succeeded in capturing me,

Each day in my cage how sorrowful are my thoughts!

I have an elderly mother who is eighty years of age,

She is blind in both eyes and she cannot fly anymore.

Above I have no elder brother, below no younger brother,

There's no one there to catch insects to feed my mother.

So I pray you, Your Majesty, to agree to set me free,

To allow me to return to the mountain and feed my mother!

Once I will have escorted my mother back to the mountain, ${ }^{74}$

I will then return to the court and be happy to recite poems."

The emperor answered the parrot in the following manner:

"You are only telling this story in order to deceive Us!

\footnotetext{
${ }^{74}$ Once I will have provided my mother with a proper burial upon her death.
} 
You are but a flying bird from the mountains,

Once I let you out of this cage, you'll forget my favor."

The parrot answered the emperor in the following way:

"Please, now, listen to what I have to say.

If I break my word, I will be happy to die:

If you catch me later, you may flay me alive!"

When the emperor heard this, he pronounced a great vow,

He opened the cage and he set the parrot free.

As soon as the parrot could get out of the golden cage,

It spread its wings and flew off, high into the sky!

It flew until it arrived at the foot of Mt. Longxi,

Where it rested on a high branch of a green pine tree.

All the birds on the mountain came together to look,

To look at the parrot that had regained its freedom.

The parrot immediately asked the hundred birds:

"Has anyone seen where my mother has gone?"

The hundred birds on the mountain all bowed before him,

Each and every lowered its head and said it didn't know.

There was only one sparrow who directly told him this:

"She was just crying on a rock in the rapids."

But when the parrot flew to the rapids to see her,

He only found there her bones and her feathers. 
The parrot pecked at the ground and wept with lowered head,

His hatred of that student was without bounds:

"As my mother has died I also want that student to die.

Even if I die, I will bring about the death of that student!"

The parrot carried its mother's bones in his beak,

And it also used his claws to gather her feathers.

He thereupon hired carpenters to saw the boards,

And make her a coffin so he could encoffin her.

He hired black crows to recite the name of the Buddha,

And they continuously recited Buddhist sutras and poems.

He hired the unicorn to select the location of the grave,

And the ants carried the corpse with their united effort.

He hired the a band of good fortune to play the drums,

And they beat the drums continuously till midnight.

He hired the black turtle to come and drink wine,

To drink wine, play drinking games, and play sad songs.

The hundred birds on the mountain all came to mourn, ${ }^{75}$

Offer condolences, shed some tears - till the rooster crowed.

Even the leeches on the mountain all came to mourn-

They all were dressed in brown shirts.

But the old eagle up in the sky did not come to mourn,

\footnotetext{
${ }^{75}$ The Chinese expression translated here as "to mourn" could be translated more literally as "to practice filial piety," or "to give expression to filial piety."
} 
All day long it roamed about in order to catch chicken.

And then the big snake did not come to mourn either,

That's why the blue snake is flayed by the people.

When all manner and kind of beast had come to mourn,

The parrot returned to court and reported to the emperor:

"My mother is buried in a grave atop the high mountain,

So I have returned to court and will recite my poems."

The emperor issued a placard to inform the whole world,

To inform all-under-heaven so all people would know

That the hundred birds on the mountain had come to mourn, And that the filial parrot had returned to court.

A filial girl works diligently at spinning and weaving, A filial son devotes himself diligently to his studies.

If a man doesn't devote himself to plowing he'll suffer hunger, If a woman doesn't devote herself to weaving she'll suffer cold.

I have sung to the end the ancient tale of the parrot, Whose fame in the world of men will endure forever. 
Collected by: Pan Xian'e and Wang Renzao.

Collected in August 1985 in the Baishuiling Miao village of Zuguan Township in Lingshui District.

Additional note: This narrative song has considerable artistic characteristics. It makes use of the story of the parrot to teach a lesson to us humans: filial piety towards our parents is a natural duty, and those who are unfilial are worse than beasts. This type of narrative folksong most often takes its materials from ancient Chinese legends, and has been widely transmitted for a long time among the Miao. 
The Song of the Toad

(Seven-syllable tune)

The Pure Pond from ancient times tells stories,

So let me sing an ancient tale for a while.

Before I sing of former kings and queens,

I will tell you everything about the toad.

Let me tell you the place of origin of a magistrate,

He lived in Yongle township in Jinzhou prefecture.

Young of years he was intelligent and also smart,

And the woman engaged to be his bride was a miss Xiao.

In a good month of a lucky year he brought her home,

A pig and goat were slaughtered for the wedding banquet.

But even three or five years after he had brought her home,

He still had no son at all who could continue the family.

Even though the magistrate searched his heart for a name,

The body of his wife showed no sign of being with child.

Husband and wife, united at heart, bought paper money,

And with pious intentions the couple prayed to the gods. 
For full fifteen ounces of silver they bought paper money,

On the altar the sacrificial offerings were arrayed in rows.

For full fifteen ounces of silver they bought holy wine,

The entire hall was filled with those many vats of wine!

They invited Daoist masters to sacrifice to the gods,

Who for three days and nights performed their rites.

Within in less than six months after these ceremonies,

The wife, through divine protection, was with child.

But before she had been pregnant for half a year,

His job required her husband to take on his office.

Her husband got ready to set out on the journey,

He entered her room and congratulated his wife.

"Since our marriage ten years passed without offspring,

So we prayed to the Buddha ands asked him for a son.

I will be at my official post, so I will not be at home-

If you give birth to a boy, raise him with care to manhood!

But if you give birth to a monster, also make sure to raise it,

Until I will come back and have seen the face of my son."

The husband mounted his horse and left from home,

His wife burst out into tears, which fell in confusion. 
When she had carried her child for the full ten months, ${ }^{76}$

She gave birth to a creature without head, without legs.

When they lifted the shining lamp to have a better look,

She discovered that the son she had born was a toad!

The angry mother immediately wanted to kill him,

But then she recalled the ten years of marital love.

The mother wanted to raise him in the flower garden

To see whether he would turn into a monster or a man.

But the toad jumped onto the belly of his mother,

He jumped onto her body, scaring her out of her mind!

And when she had raised the toad for half of month,

Her husband came back and returned to his village.

When the magistrate at that time came back home,

He entered the bedroom with his head and steps lifted high,

When he asked whether the baby was a boy or a girl,

His wife found it impossible to tell him the truth:

"Other people all easily give birth to a noble son,

But here in this family, alas, our child is a monster!"

When husband and wife went into the flower garden,

The toad jumped onto the body of the magistrate!

The scared magistrate fled in leaps and bounds,

\footnotetext{
${ }^{76}$ In China a pregnancy is said to last ten months, as one counts from the month in which the baby is conceived to the month in which the baby is born.
} 
He raised an axe and he wanted to split its skull!

The toad hopped off into the flower garden, and

Husband and wife returned to their room, and wept:

"We spent thousands and thousands on merit-making,

Who could have guessed the result would be such a monster!"

One moment he wanted to chop off its head,

Then he recalled the ten years of marital love.

It happened that barbarians raised a large army,

And the emperor posted a placard at the palace gate. ${ }^{77}$

The officials were flustered when seeing this placard,

But the toad took the placard and hopped back home.

When the magistrate was informed of this news,

He definitely wanted to take this creature and bury it alive.

But a clerk stepped forward and told the magistrate:

"Mr. Magistrate, please listen to what I have to say.

You may want to beat this toad to death,

But whom will you have return the placard to the emperor?

When the toad carried away that placard yesterday,

Officials and people all saw him pass on the road!"

\footnotetext{
${ }^{77}$ In traditional Chinese narrative, when the emperor is at a loss what to do, he will post a placard outside the palace offering a large award to the person who will come to his rescue. The person who believes he can meet the challenge takes the placard away and reports to court.
} 
The magistrate nodded and said: "You are right,"

And promptly sent the clerk to report to the emperor.

The emperor dispatched a commissioner to Jinzhou:

"Who ever took away the placard, may ascend the chair!",78

The toad in the garden was truly gifted with understanding,

Holding the placard he came hopping to the office gate.

The guardsmen could not stop themselves from laughing:

"How have we come up with such a commander of the army!

Please take your seat in this golden sedan-chair,

In the capital you will definitely be buried alive!"

When one day they had arrived at the Golden Bell Hall,

The toad jumped onto the base of the emperor's throne.

The emperor addressed him from outside of the hall, asking:

"How will you chase the barbarians from the border region?"

The toad replied the emperor in the following words:

"Now you listen carefully to what I have to say!

On the placard you say you have a Third Princess--

'Whoever chases the barbarians away will be her husband!'

You have to establish a contract written in your own hand,

Only then will I go off to the steppe in your service!"

The emperor answered the toad in the following manner:

78 The "chair" here refers to a sedan-chair. 
“Upon victory you'll marry my daughter-no problem!

Now I want you to kill the tartar rebels,

How many swords and lances do you need?

The toad immediately replied in the following manner:

"I will need one red banner of one rod and two feet high.

I also want one horse with a black mane,

And two soldiers to accompany me."

The toad jumped onto the saddle of his black horse,

The red banner unfurled and pointed towards the north.

Immediately he arrived at the location of the barbarians:

One gust of an easterly storm—really irresistible!

From his left nostril the toad blew a violent fire,

From his right nostril came a riot of flames and smoke.

As the toad blew his fire, it shook heaven and earth,

It burnt the barbarian troops until they were completely dead!

Beating the gong he collected his troops like the wind;

Returning to the rumble of the drums he met the emperor:

"As I have utterly defeated the country of the barbarians,

I now come forward to take Third Princess as my bride!"

The emperor secretly conceived of a plot, He grabbed a toad and compared the two: 
"You two are articles of the same class,

So how could you marry my Third Princess?

You are only as big as the cover of a wok,

You look like a monster—how could you be the groom?

I will give you a hundred loads of gold and silver-

Take them home with you to take care of your parents!”

When the toad heard this, his breast was filled with rage:

"You are the emperor, yet you lie as soon as you speak!

How can you rule the country and order the populace?

The whole world will sink into chaos, disaster will strike!

In case Third Princess is not given to me as my bride,

I definitely will rise in rebellion here inside the court!"

The emperor was so frightened his heart was alarmed,

And, speaking, he promptly made the following promise:

"Here and now I set the date as the ninth of the Ninth Month,

Send whatever matchmaker you like to fetch the bride!"

When Third Princess heard what her father had promised,

She sat awash in tears inside the bed-curtains of pearls:

"They want me to go and marry a man who is a toad!

I would rather die to be reborn at some later date.”

When her birth-mother heard that her daughter was unwilling,

She tried to talk her around with well-meaning words: 
"In case you refuse to marry that man who is a toad,

He will put this city to the torch and kill your parents!"

The emperor, seated on his throne, asked the chancellor:

"How can we take care of this unpleasant matter?"

The chancellor answered the emperor as follows:

"Alas, this princess since her birth has resented her fate!

I have been an official for a full sixteen years, yet

Only now have I seen the force of the fire of a toad!

The barbarians prided themselves on their millions of troops,

But they all are afraid of the strength of this toad!"

When the emperor heard him speak in this manner,

His heart was sad and his guts in turmoil!

But that very moment he secretly conceived of a plan,

A plan capable of passing the seas, deceiving the mountains!

He ordered that three thousand palace maidens be summoned,

These three thousand girls were all to dress the same.

These three thousand girls would be arranged in rows,

The one to be picked as bride would suffer that fate!

In the third watch of the night our toad had a dream,

In which the Great White Star Lord ${ }^{79}$ informed him:

\footnotetext{
${ }^{79}$ The Great White is the planet Venus. The god of the Great White appears in many traditional stories as the helper of a deserving protagonist.
} 
"They all wear on their head a 'nine-month valley, ${ }^{80}$

But the one with the yellow bee is Third Princess."

Our toad was very happy when he had seen this dream,

And he memorized it in his heart as dawn approached.

The emperor was formally seated in the Golden Bells Hall,

Where he called to the toad to him and said to him:

"These three thousand girls are all dressed the same,

It's up to you to select from them my Third Princess.

If you select one of the palace girls, it's your bad luck,

But if you select Third Princess, you are the winner."

The toad hopped into the palace hall and waited in hiding,

As the brigades of palace girls all lined up in rows.

Our toad secretly listened very carefully till he heard

How the buzzing yellow bee told him it was Third Princess.

With one jump the toad grabbed the hand of the girl:

"Young lady, let's tie the knot as mandarin-ducks!"

The officials and officers all shook their head and sighed:

"Alas, that such a monster should burn such fine incense!"»1

In front of the hall the chimes were struck and resounded:

\footnotetext{
${ }^{80}$ From the context it would appear that the “ninth-month valley” (jiuyuegu 九月谷) is some kind of flower, but I have been unable to identify this term.

${ }^{81}$ I.e., "Too bad that such an ugly creature will be allowed to enjoy this fine young lady."
} 
The toad was welcomed and guided into the bridal chamber.

That night then the toad was lying prostrate on the bed,

While the princess soaked her side of the bed with tears.

When he had slept till midnight, the princess saw

How the toad turned into a handsome young groom.

The toad took off his clothes and put them by the bed,

Third Princess remade her toilette before the mirror.

When the two of them saw each other, desire was aroused,

Hand in hand they retired behind the gauze bed-curtains.

A spring breeze moved the curtains into gentle waves

As they undid their buttons and united as mandarin-ducks!

They slept till the rooster crowed and the sky was bright,

Then they combed their hair and dressed inside their room.

Husband and wife emerged together from the bed-curtains,

Side by side, holding hands, they entered the court-hall.

The emperor in front of the hall laughed very happily,

Deeply moved by his darling daughter's good fortune.

The emperor opened his mouth to proclaim an imperial edict:

"May all come to court and congratulate the groom!"

The civil and military officials all raised their cups,

While the chimes resounded they drank the fine wine.

Third Princess opened her mouth to request of the emperor: 
"Please have someone go and fetch my parents-in-law!"

The magistrate and his wife mounted their horses,

And they immediately arrived before the palace.

The emperor welcomed the magistrate before the hall:

"I have to thank your son for saving my life!"

The emperor before the hall personally raised the cup,

Greatly praising the magistrate from Jinzhou for his virtue.

Accompanied by a thousand soldiers he returned home,

And everywhere people called him a prince of the blood.

Now I have sung to the end the ancient song of the toad,

Which is famed throughout the five lakes and four seas.

The persons who provided the hand-written manuscript: Deng Wen'an and Qiu Yajin ${ }^{82}$ Collected by: Pan Xian'e and Wang Renzao

Collected in October 1985 in the Baishuiling Miao village of Zuguan Township in Lingshui County.

\footnotetext{
${ }^{82}$ The text actually writes Deng Yajin, but in the case of all other songs attributed to Deng Wen'an and someone else in Zhongguo geyao jicheng: Hainan juan, the name of the second person is written as Qiu Yajin. In manuscript the two characters deng and qiu easily can be mistaken for each other.
} 
Additional note: This narrative song is widely popular among the Miao, and it is sung in every Miao village, with minor variations in plot. The Song of the Toad which is popular in the region of Tongshi city ${ }^{83}$ also deals with this story, but it is sung in the form of a series of questions and answers. This story is also popularly told among the Li, and the content is largely the same, but so far we have not discovered a Li song that sings this story.

\footnotetext{
${ }^{83}$ Most of the Miao materials in the Hainan volume of the Zhongguo geyao jicheng that do not derive from the manuscripts in the possession of Deng Wen'an are based on oral performances from the city of Tongshi 通什 (the name of this city was changed to Wuzhishan 五指山 in 2001). This might have to do with the fact that in the appendix giving information on “important singers" (zhuyao geshou 主要歌手) in Zhongguo geyao jicheng: Hainan juan, pp. 599-604, the only person identified as belonging to the Miao minority, Jiang Da'en 蔣大恩, is from there (pp. 603-604). Looking at the appendix in the same volume that lists the performers, collectors, and transcribers for the volume, of the 16 districts or cites listed, the place with the highest number of persons identified as Miao is actually Tunchang 屯昌 District with three. Tongshi has only one, but that person is not Jiang Da'en. The only other districts or cities for which a Miao participant is listed are the districts of Lingshui (the source of the first three ballads translated here) and Changjiang 昌江 (the source of the fourth ballad). All four of these places are widely separated from each other. Lingshui and Changjiang are Li autonomous districts, but Tunchang is not.
} 


\section{Zhang Meng'e}

(Seven-syllable tune)

Since ancient times the Miao have many fine women:

Let me now sing for a while the tale of Zhang Meng'e.

Squire Zhang had no sons, but he sired two daughters;

Both these girls, the two of them, surpassed all men.

The eldest daughter was called Zhang Zhubao,

The second daughter was called Zhang Meng'e.

The eldest daughter knew by nature how to weave cotton;

The youngest daughter knew by nature how to weave silk:

She could weave unicorns facing lions;

She could weave mandarin ducks facing phoenix couples. ${ }^{84}$

Even when Meng'e had reached the age of eighteen years, She never had yet gone outside the main gate of her house.

But when Clear and Bright came around in the Third Month, The sisters went outside to enjoy the fragrance of flowers. Squire Zhang addressed them, giving them his instructions,

\footnotetext{
${ }^{84}$ There is no personal pronoun in the original in this and the preceding line, and while it would be justified to take both lines as referring to both sisters, it seems to make more sense to make them refer to Meng'e alone, since Zhubao plays little part in the story below, and there is certainly expressed concern over matching her up with a husband.
} 
And the sisters displayed their respect by making a bow.

The two of them put on their finest and did up their hair,

They put on their finest — they went out to look for a man!

In their hair they stuck hairpins of gold of various length;

With faces like peach blossoms they surpassed immortals.

From the eastern village they passed to the southern village;

From the western village they turned to the northern village. ${ }^{85}$

They saw that the peach trees had opened their blossoms:

Half of each tree was green and half of each tree was pink ${ }^{86}$.

Honey bees moved over gathered flowers - couple by couple,

Butterflies were flying over the trees-pair by pair.

Yan Hui was dressed on this day in fine satins and silks;

Whipping his horse he passed by and noticed Meng'e.

This meeting today was a match predestined by karma:

Two mandarin ducks united in feeling, both of one mind.

When Yan Hui came back home, he informed his father:

"If I could marry Meng'e, even death would be sweet!"

So when Squire Yan had heard this declaration of love,

He silently pondered this matter at length in his heart.

The next day he immediately sent a matchmaker to go,

\footnotetext{
${ }^{85}$ Needless to say, there is no attempt to describe a real itinerary here.

${ }^{86}$ The green is the leaves and the pink (literally, red) is the flowers of the peach trees.
} 
To go to the Zhangs and to propose this marriage plan.

When the matchmaker arrived at the house of Squire Zhang,

Squire. Zhang invited her in and they sat down in the hall.

After three cups of wine the matchmaker said to him:

"It is common knowledge that you have a daughter.

Squire Yan has dispatched me to come and ask after her,

He hopes to send engagement gifts and conclude a match.”

Squire Zhang answered the matchmaker in this manner:

"If their years and fates do match, they can become a couple."

When the matchmaker received this reply, she quickly returned,

And told the Yan family to hurriedly prepare their presents.

Squire Yan opened his storehouse of gold and silver,

And the ten kinds of ritual presents were all prepared.

Three hundred carriers transported the ritual presents,

And delivered them to the Zhangs to engage Meng'e

But before half a month after the delivery of presents

Yan Hui attracted a disease that confined him to his bed.

On the first of the month she got news the groom was ill;

On the second of the month got news that he had passed away.

Putting down her "hemp bow" she read his letters,

The tears flowing from her eyes made a pair of streams.

She took out her hairpins, wrapped her head in a mourning scarf, 
And was about to go to the Yans to burn incense in mourning.

"My daughter, don't be so sad, another husband we'll find!"

But Meng'e answered her father in the following way:

"Father, I’ve made up my mind I will never remarry.

When has a single ox ever borne two collars?

When has a single horse ever carried two saddles?

When has a single bow ever shot two arrows at once?

When has one woman ever married two husbands!

You'll never find a single horse with two saddles,

One woman with two husbands would be laughed to death!"

When Squire Zhang heard this, he had no words to respond;

When his daughter wanted to go he did not prevent her.

Meng'e, with flowing tears, arrived at the Yans,

She opened the coffin to gaze at the spiritless corpse.

When she had finished crying, she spoke these words:

"I will live on in the Yan family, I will never go back,

And in this life I will never marry a second husband.

Yan Hui was short-lived and not able to repay his parents,

Meng'e will most filially care for her parents-in-law."

When Squire Yan had heard this, he was deeply moved:

"She is not our own daughter, but she surpasses a son!"

Meng'e fulfilled her filial duties in the Yan family, and 
Far and near in the mountains the Miao all praised her.

Performed by Jiang Mingxin

Collected by Li Zhengmin and Ma Zhongchuan

Recorded Miao Village in Chicha Township of Changjiang District in April 1987.

Additional note: This Zhang Meng'e, and the Song of Yan Hui that is popular in the area of Tongshi, are both songs that use the same stuff material. We have here selected this song. This song uses the form of direct narration to sing the story, whereas the Song of Yan Hui uses the form of a sequence of questions and answers to sing the story, but in terms of content, both songs describe the tragic marriage and love of Yan Hui and Zhang Meng'e. While praising love that is constant and true, they also propogate and honor the views on chastity of the feudal society. From these two songs one may get a glimpse of the Miao's ancient notion of love, and the influence of the cult of chastity on the Miao. As far as text and language are concerned, this song belongs to the sinified ballads. 